\title{
Counselling Needs Among Primary School Learners: The Role of School Counsellor
}

\author{
Magwa Simuforosa \\ Department of Educational Foundations \\ Faculty of Education, Great Zimbabwe University \\ Chindanya Loveness \\ Department of Educational Foundations \\ Faculty of Education, Great Zimbabwe University
}

\begin{abstract}
Many school children are not achieving in school often coping with emotional problems, a chaotic family, mental health, and poverty. This paper set to examine primary school behaviours indicative of guidance and counselling needs in Masvingo district, Zimbabwe. The study is grounded in Carl Rogers's person-centred theory. A qualitative case study was employed. A sample of 36 participants comprising school counselors, school heads and grade 6-7 learners were used. Data was collected through use of questionnaires and interviews. The results revealed that primary school kids encounter problems like bullying, failing to make friends, inattention, and emotional symptoms. It also emerged from the study that school counselors can come up with intervention strategies to help pupils encountering such problems to live functional and meaningful lives. The researchers therefore recommend that all heads and teachers need to be sensitised through seminars and workshops to give adequate support to Guidance and counseling (G\&C) programmes in order to help learners facing various challenges hindering them from learning. There is need to improve the level of training of school counselors in guidance and counseling
\end{abstract}

Key words: Indiscipline, primary school, counseling, counselor, intervention, therapy

\section{INTRODUCTION AND BACKGROUND TO THE STUDY}

Primary education as the name implies is prime, sensitive, precious and crucial for laying the foundation for the overall development of children. It is the basic or introductory schooling that children receive from 6 continuing to 11 years (Nram, 2005). There is ample research evidence that successful adult intellectual development has its roots in primary education. A sound primary education is a pre-request to sound secondary and tertiary education.

Primary school children face a lot of developmental problems which hinder intellectual, physical, social, emotional and moral development. They encounter problems such as truancy, lateness to school, and poor study habits (Egbo, 2015; Anagbogu, Nwokdo, Anyamene, Anyachebelu and Umezulike, 2013). All these dimensions of Primary school children's problems raise a lot of concern to parents, teachers and counselors. Whisman and Hummer (2014) cite a study in West Virginia in the USA which revealed that about $29.6 \%$ of 16,480 students from grade 3 - 11 had one or more referrals for inappropriate behaviours. Research shows that various discipline problems exist among primary school pupils including truancy, cheating, absenteeism bullying, failure to complete assignments, pornography, and vandalism (Samba, Agak and Kaboka, 2016). Indiscipline leads to ineffective teaching and learning and production of unacceptable members of society (Magwa and Ngara, 2014). 
It has been estimated that $12 \%$ of the primary school going children are so emotionally upset as to require the services of educational psychologists and guidance and counseling specialists Blair, Jones and Simpson, 2010).

Going by the revelation of the afore mentioned studies both globally and locally, indiscipline among pupils needs serious interventions. Counseling is most needed at this stage since the children are in their formative years. Counseling is defined as a discipline that helps students not to be tormented by their internal conflicts and not to resort to self-destructive strategies. Counseling addresses the personal, academic vocational and social needs of children. Primary school children need developmental and preventive counseling, rather than remedial. Whisman and Hummer (2014) asserts that counseling of primary school children is in three dimensions namely resolution of problems, prevention of problems and growth counseling so as to enable the children to develop hidden potentials and capabilities.

The need for people to live functional and meaningful lives makes it imperative that early guidance and counseling programmes be established at primary school level. This study is imperative because maladjustment problems in later stages of life (at secondary and tertiary) can be averted at formative stages by a applying Guidance and Counseling to stem such problems as juvenile delinquency, sexual abuse, and drug abuse.

\section{STATEMENT OF THE PROBLEM}

Many children are not achieving in school often coping with mental ill health, emotional problems, and poverty. Very little attention is being paid to guidance and counselling services at primary school level.

\section{RESEARCH QUESTIONS}

1. What are the childhood behaviours indicative of guidance and counseling needs?

2. What is the role of the counselor in assisting pupils encountering various problems which affect their well-being and educational outcomes?

\section{SIGNIFICANCE OF STUDY}

It is envisaged that the study results will help the school heads and school counselors develop appropriate measures to counseling programmes in the school. The students can be helped discover their skills and talents. The level of discipline will improve, thus enhancing performance of learners. The study results will also provide researchers with baseline information that could be useful in future guidance and counseling research studies.

\section{THEORETICAL FRAMEWORK}

This study is hinged on Carl Rogers's person-centered theory. The person-centered theory was designed to promote openness, growth and change in the clients. It is a process of helping clients discover new and more satisfying personal meanings about themselves and the world they inhabit (Gatongi, 2007).

The model assumes that human interaction is only possible when conditions such as empathy, unconditional positive regards (UPR) and congruence are demonstrated by the counselor (Gatongi, 2007). Empathy as a core condition in person-centered counseling is to sense the client's private world as if it were your own. Rogers (1957:99) says empathy is entering the "shoes" of the client. When the teacher counselor appears to understand how a pupil feels he/she is showing empathy. The more the counselor sees the world from the pupil's perspective, the more he /she is able to help. 
According to Rogers (1961) congruence, sometimes called genuineness is characteristic of being transparent, real and honest in a helping relationship. No professional mask should be put. Counselors should be open and willing to share their own experiences with pupils.

Unconditional positive regards is a non-judgmental warmth or acceptance where client feels received in a humane way which is non-threatening (Rogers, 1957). Fox (1993) asserts that the pupils should believe the teacher feels positively towards them. This should be unconditional and not depend on the pupil fulfilling all the things a teacher likes for an ideal pupil.

The three conditions enhance effective and caring relationships. As rightly argued by Rogers, the counselor who provides the right conditions in counseling relationships will enable clients to choose to become true to themselves (Thorne, 2003).

\section{Design}

\section{METHODOLOGY}

This study adopted a qualitative case study. The case study design primarily focuses on micro level issues, studying people in their natural settings in order to identify how their experiences and behaviours are shaped by the contexts of their lives such as the social, economic and physical (Tweksbury, 2009; Hossain, 2011).

\section{Sampling}

Shizha (2007) contends that in qualitative research the size is typically small, the most important issue being the in-depth study of the phenomenon under consideration. Given these views on sampling in qualitative research, the sample for this study consisted school counselors, school heads and learners who were all selected on basis of purposive sampling. According to Magwa and Magwa (2015) the aim of purposive sampling is to select participants who are knowledgeable with regard to phenomenon under study. The sample consisted of 4 school heads, 8 school counselors and 24 learners bringing to a total of 36 participants.

\section{Instrumentation}

To obtain information on topic under study, questionnaires and interviews were utilized. Interviews were preferred because as asserted by de Vos; Strydom; Fouche, and Delport, 2012.) the researcher(s) is able to probe further, follow up, clarify issues and ask for elaborations from the interviewee. Semi structured interviews were used- with school counselors.

On the other hand questionnaires were also employed since they are time consuming and allow for anonymity of the respondents which may give rise to honest and answers (Magwa and Magwa, 2015). School heads and learners completed questionnaires.

\section{Data Analysis}

Qualitative data produces voluminous amounts of raw data. To give meaning to this raw data, analysis of the data has to be made. Cresswell (2010) and Henning (2004) are of the view that qualitative data analysis is a search for general statements and underlying themes. In this study the researcher identified themes and relationships from the raw data......

\section{Ethical considerations}

Permission was secured from selected school heads, school counselors and learners. The identity of the participants remained anonymous throughout the study. With insights from 
Magwa and Magwa (2015) participants were informed that their involvement in the study was voluntary and that they were free to withdraw from participating at any time.

\section{FINDINGS AND DISCUSSION}

Sub-headings representing themes or categories that emerged as the main themes on were used to facilitate the presentation and discussion of findings. The emergent main categories were bullying, socially withdrawn, inattention and depression.

\section{Bullying}

The study established that bullying among primary school learners was a behavior indicative of guidance and counseling needs. Bullying as a conduct problem was regarded as a behavior problem in individuals that fails to conform to societal norms and encroach on the right of others. All the participants were of the view that bullying which involves name calling, hitting, and spreading false rumors is a problem with negative outcomes on the bullied and school. The findings are confirmed by the following quotes:

- The bullied feel unhappy and want to avoid school.

- Those bullied are at increased risk of misbehavior, and absenteeism.

- Bullying leads to poor academic performance.

Jan and Husain (2015) note that bullying creates barriers to learning. Several negative mental, social, psychological and physical outcomes are associated with bullying. Similarly, James (2010) contends that bullying has an effect on concentration span as the bullied will be worried about when and how they will be bullied.

Having regarded bullying as having long term impact in childhood participants were asked how the school counselor can offer help. Findings from the three research instruments indicated that the school counselors should teach students skills and behaviors to combat bullying. One interviewee had this to say:

Counselor should address staff, students and parents on warning signs, causes and impact of bullying victimization..

Bauman (2008) explored the role of school counselors in reducing school bullying and established that school counselors need to be knowledgeable about types of bullying, location of bullying, and insist that policies and interventions targets more than physical bullying.

Thus school bullying is an evident problem in primary school. The school counselor plays an intervention role in reducing bullying.

\section{Difficulty making friends}

Findings from this study confirmed that among primary school learners there are some children who are unsocial or withdrawn. They find it difficult to make friends. Social withdrawal was seen as the consistent display of solitude when in company of familiar or unfamiliar peers. The following quote by one interviewee portrays the characteristics of such children:

Socially withdrawn pupils have poor self-esteem. They feel lonely and experience school difficulties. They withdraw from social activities.

The study established that children who enjoy strong and positive relationships with peers fare well in their social and school work. Social competence with peers was said to be significant as it relates to future behavior in adolescence. Research findings by Elliot, McKevitt and DiPerma, (2002) concur that the ability to interact successfully with peers and adults is an 
important developmental accomplishment for children. Experiences of absence of friendship and peer rejection is predictive of psychopathology, school dropout and delinquency (Achenbach and Edelbrock, 1981)

The participants agreed that interventions programs need to be implemented to help children develop social lives. The study noted that school counselors should deliver counseling as a talking therapy and provide support through none-directive play therapy. Brigman, Webb and Campell (2007) assert school counselors should provide early intervention social skills programs for teaching social and self-management skills. Play therapy as echoed by Landreth (2002) is considered one of the most effective therapeutic interventions for young child. It provides an opportunity for the child to fully express and explore thoughts, feelings and behaviors through medium of communication.

\section{Inattention}

Another issue affecting the well-being and educational outcomes of primary school learners needing counseling noted by the study was inattention. From the questionnaires and interviews it emerged that some children seem not to take notice of what is going in the classroom. Their learning is disturbed. The words of one female teacher counselor reflect many participants' sentiments on difficulties encountered by children with inattention problems.

In the classroom pupils who are inattentive are very forgetful. They lack concentration, struggle to do homework and make a lot of errors in both oral and written work.

According to American Psychiatric Association (2013) inattentive children fail to give close attention to details. Problems with inattention are problematic to academic performance. These children are further said to submit messy or incomplete work. The difficulties as established by the study and as reflected in literature prompt requests for help from school counselors. The counselors may help children develop intrinsic motivation to help children gain confidence in their training sessions that indicate how to set up a tangible reward system that provides means for the teacher to give reward to child for paying attention (American Psychiatric Association, 2013).

\section{Emotional symptoms - Depression}

Amount of stress children today are faced with is overwhelming (Woolfolk, 2010). The study revealed that a number of primary school learners experience stress which affects their wellbeing and educational outcomes. These emotional symptoms were said to be as a result of environmental, family and school factors. The qualitative inquiry managed to identify the following as contributing to everyday stressors of pupils: too much homework, death in family domestic violence in the home, sick parents, and poverty. Woolfolk, (2010) and Frank (2003) also assert that there are many cases of inside and outside of schools that lead to stress among pupils such as family financial strain, divorce, step parents, homelessness, failing grades, and increase in amount of homework.

As noted by the participants there are steps counselors can take to help children deal with stress such as employing student centered counseling. Another role of the counselor noted by the study was creating stress reduction activities such as Art activity, exercising, getting good amounts of rests, and being with friends.

In line with the findings of this research, Frank (2003) asserts that counselors can make use of the person centered therapy. The counselor will allow the child to be heard, listened to and to vent out what is bothering them. Empathetic responses from counselor will help in changing a 
situation for the better. In addition, Frank says involving family members, working together as a support system can influence changes in stress in a child. Family therapy thus, can help overcome the problem behavior.

\section{CONCLUSION}

Primary education forms the bedrock upon which the entire system of education depends. Many of the primary school children are not achieving in school as a result of different psychological problems (Ogunsanm, 2011; Bauman, 2008). They encounter problems from bullying, peer rejection, day dreaming, sexual abuse and failing grades among others. School counselors have a critical role to play in helping to stem these problems at the formative stages thereby leading them to succeed and fulfill their dreams. Counseling is shown to be effective intervention for primary school children with a positive impact on attendance, academic achievement and behave

\section{RECOMMENDATIONS}

- School counselors should take an advocacy and leadership role in helping reduce the occurrence of problems among pupils.

- Parents should be sensitized on the importance of guidance and counseling on pupils' behavior change.

- Guidance and counseling programs at primary level need to be strengthened in order to improve the academic performance of learners.

- Teachers should be trained in counseling.

\section{References}

Achenbach,T. and Edelbrock, C. (1981). Behavioural problems and competencies reported by parents of normal and disturbed children aged through four to sixteen. Monographs for the society for research in child development, Vol 46 (1) pp 82-94.

American PsychiatricAssociation (2013). Diagonostic and stastically manual of mental disorders. (5th edition) Arlington, V.A: American Psychiatric Publishing.

Anagbogu, M.A. , Mwokdo, C.N.,Anyomene, A.N.,Anyachebule, F.T. and Umezulike, R. Q (2013) Professional challenges to counseling practice in primary schools in Anambra state, Nigeria: The way forward. International Journal of Psychology and Counselling. Vol 5 (5) pp 97-103.

Bauman, S. (2008).The role of elementary school counselors in reducing school bullying. Elementary School Journal, Vol 108 P 362-275

Blair, GM Jones R.S And Simpson, H. R (2016). Educational Psychology: London: MacMillan.

Brigman, G.,Webb, L. and Campbell, C. (2007). Building skills for school success: Improving the academic and social competence of students. Professional school Counselling.Vol 10. Pp 279-288.

Cresswell, J W. (2010). Qualitative inquiry and research design: Choosing among five traditions. Thousand Oaks, CA: Sage.

de Vos, A S.; Strydom, H.; Fouche, C B and Delport, C S. (2012). Research at grass roots. Pretoria: Van Schaik Publishers.

Egbo, J. E. (2015). Need for Guidance and Counselling at primary school level: Early intervention strategies for school children. British Journal of Education. Vol 3 (6) pp 1-8.

Elliot, S. N., McKevitt, B.C. and DiPema, J.C. (2002). Promoting social skills and development of socially supportive learning environments,. In S.E. Brock, P.J. Lazarus and S.R. Jimerson (Eds). Best practices in crisis prevention and intervention in schools.

Fox, M. (1993). Psychological pespectives in Education. London: Cassell Education Limited.

Gatangi,F. (2007). Theory and Practice: Person centered approach in schools: is it the answer to disruptive behaviour in our classroom?Counselling Psychology Quarterly, Vol 20(2) 205-211.

Henning, E (2004). Finding your way in qualitative research. Pretoria: Van Schaick. 
Hossan, D M. 2011. Qualitative research process. Postmodern Openings, 7:143-156.

James, A. (2010) School bullying. Available at http://iamnotscared.pixel-

online.org/data/database/publications/384_NSPCC\%20Briefing.pdf ( Accesed 10/02/17).

Jan, A. and Husain, S. (2015). Bullying in Elementary Schools: It causes and effects on students. Journal of Education and Practice. Vol 6 (19)

Landreth, G.L. (2002). Play therapy: The art of the relationship (2 $2^{\text {nd }}$ ed) New York: Routledge.

Magwa, S and Magwa, W. 2015. A Guide to conducting research: A student handbook. Texas: Strategic Book Publishing Rights Co., LLC.

Magwa, S and Ngara, R. (2014). Learner indiscipline in schools. Review of Arts and Humanities, Vol 3 (2) 79-88.

Ogunsanmic, J.O. (2011). Awareness of teachers on the effectiveness of guidance and counseling in primary schools in Nigeria. International Journal of Academic research in Business and social sciences.Vol 1 (Special issue)176-183.

Rogers, C.R. (1957). The necessary and sufficient conditions of therapeutic personality change. In B.T. Broadley (Ed) Instructions for beginning to practice client-centered therapy. Chicago: Illinois School of Professional Psychology.

Rogers,C. (1961) on becoming a person. Boston: Houghton Mifflin Company.

Samba, N.O., Agak, J. O., Kaboka,E.K, (2016). Impact of discipline on academic performance of pupils in public Primary Schools in Muhoroni Sub-Country,Kenya Journal of Education and Practice, Vol 7(6 ) 164-173.

Shizha, E. (2007). Critical analysis of problems encounterd in incorporating indigenous knowledge in science teaching by primary school teachers in Zimbabwe. The Alberta Journal of Educational Research, Vol 53(3) pp 302319.

Tewksbury, R. 2009. Qualitative versus quantitative methods: Understanding why qualitative methods are superior for criminology and criminal justice. Journal of Theoretical and Philosophical Criminology, Vol 1 (1): 3858.

Thorne B. (2003). Carl Rogers: Key figures in counseling and psychopherapy series. London: Sage.

Whisman,A. and Hammer,P.C. (2014). The association between school discipline and Mathematics performance: A case for positive discipline approaches.WV: West Virginia department of Education, Division of Teaching and learning, Office of research.

Woolfolk, A. (2010). Educational Psychology 11thEdition. London: Pearson Education International. 